\title{
Innovations in the Management of Zakat to Increase Entrepreneurial Interest and Poverty Reduction in Indonesia
}

\author{
Pertiwi Utami 1,a* ${ }^{\text {(D) }}$; Basrowi 2,b; Muhammad Nasor ${ }^{3, c}$ \\ 1 pertiwiutami@stebilampung.ac.id; ${ }^{2}$ basrowi@binabangsa.ac.id; ${ }^{3}$ nasor@radenintan.ac.id \\ a Sekolah Tinggi Ekonomi dan Bisnis Islam (STEBI) Lampung, Indonesia \\ b Universitas Bina Bangsa, Indonesia \\ c Fakultas Dakwah dan Ilmu Komunikasi UIN Raden Intan Lampung, Indonesia \\ * corresponding author
}

\section{Abstract}

The purpose of this study is to propose the management of BAZNAS, which could become one of the role models of digital zakat because it is pretty successful in managing zakat and the use of digital technology to create the interests of the people. Literature studies are used to reveal the usage of digital technology in BAZNAS and how to develop digital entrepreneurship in the future. The study showed that the BAZNAS digital zakat program could reduce poverty due to empowering mustahiq through digital entrepreneurship and digital technology innovation in the form of rice atm. Other digital technology implementations are digitizing zakat payments, application-based digital information technology services for muzzaki, and blockchain ( $i$ zakat) in managing digital zakat. For the development of digital entrepreneurship, the role of government, universities, and BAZNAS

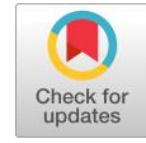

Article history Received 2020-03-31

Revised 2020-09-23 Accepted 2021-03-01

Keywords

Innovation management Entrepreneurship Zakat Poverty reduction must be able to work well together. The BAZNAS Model digital zakat program can be a valuable reference for global zakat managers in improving digital entrepreneurial practices and zakat distribution innovation. The implications of this research are the results of observations on the practice of using BAZNAS digital zakat technology in the management of zakat based on a theoretical basis using an Islamic economic approach.

This is an open access article under the CC-BY-SA license.

\section{Introduction}

Islamic countries, especially the Organization of Islamic Cooperation (OIC), currently require drastic and empirically justified solutions to significant changes in efforts to overcome economic difficulties, especially the problem of unemployment in the digitalization era. In line with this, the rise of zakat is one of the hottest issues to reduce poverty in Muslim countries. The Organization 
of Islamic Cooperation (OIC) is an umbrella body capable of bridging unity, cooperative relations, and narrowing disparities between countries in the Islamic world. At present, the OIC requires strategic and empirical solutions for poverty alleviation, especially unemployment. As many as $21 \%$ of the population of the Islamic Cooperation Organization (OIC) or around 350 million Muslims are struggling to defend their lives in the economic bondage. Therefore, the Republic of Indonesia and the OIC countries encourage zakat to be a solution. One of them is through financing development for the welfare of the people. This agreement is a form of government support and OIC countries to Amil zakat institutions as a source of Islamic social finance to help build the economy of the poor amid the economic crisis. And this is one form of the role of Islamic finance in increasing financial inclusion in the OIC (Moheildin, et. al., 2011).

One study revealed that "The ratio of zakat to GDP exceeds the poverty gap index of GDP (PGIGDP) in all OIC countries except for three countries, with a poverty line of $\$ 1.25$ per day. With a catalyst, Zakat institutions have a lot of potentials to contribute to poverty alleviation. Besides, the aggregate resources collected together from the potential for zakat in 17 OIC countries will be sufficient to fund resources for poverty alleviation. "Opportunities for zakat potential that is large make various international zakat forum activities encouraged. Plus, the development of technology 4.0 is increasingly becoming a necessity in the financial industry. Zakat funds are a very urgent and potential part (Puskas BAZNAS, 2019). One of the hottest issues is the role of optimizing zakat in the world through the digitalization of zakat. Even in the medium term, the OIC members will enter all of the world's zakat forum activities, which now has 33 countries, including Indonesia, represented by BAZNAS (National Amil Zakat Board) (Republika.co.id, 2019).

The contemporary human resource management (HRM) framework by zakat institutions is the most common way to manage zakat (Hasan, et al, 2019). However, over the times, "Digitalization of Zakat emerged and provided great benefits including digital finance makes the collection and management of zakat more efficient, transparent and massive, reducing costs in transactions, being able to reach people including millennial generation, and being able to improve the security of collecting and managing zakat nationally (Syuryana \& Murdaningsih, 2018)." The development of technology entering the Era of Technology transformation 4.0, it is expected that zakat institutions can apply efficiency and effectiveness in the implementation of zakat management operations (Monjelat \& Jamila, 2019). Also, the facts show that there are still many zakat institutions that have not yet reached the goal of the Maqasid Sharia as the community has little trust in these institutions, and some of them choose the traditional way (Ahmad, 2019; Canggih, Fikriyah \& Yasin, 2007; Kashif, Jamal \& Rehman, 2016).

To improve performance in the management of zakat, BAZNAS innovates in the distribution of zakat by developing a sharia-based digital entrepreneurship program for the poor. Sharia values have a mediating role in the relationship between innovation and the development of sharia-based 
products or services. Therefore, strategic sharia innovation can be carried out by updating products that are in accordance with the ideal structure between those supported (Mansur, Suliyanto, \& Rahab, 2019; Laldin \& Furqani, 2016).

Research on innovation and digital entrepreneurship generally requires stable or fixed boundary assets for new product or service ideas that form the basis of entrepreneurial opportunities. Most digital product designs can be expanded by various innovators who participate in the development of digital entrepreneurship (Lyytinen, Yoo, \& Boland, 2016). Mintzberg (1989) identifies the role of entrepreneurship in decision-making, where managers start and oversee projects to improve company performance. Digital entrepreneurship was chosen because it was felt to be very suitable for improving BAZNAS performance. The main reason is that digital entrepreneurship has a high topic because the development of technology development and infrastructure advancements create various opportunities for the middle to lower classes. As the findings made by Todaro and Smith (2003) revealed, entrepreneurship can affect the level of economic growth of a country because it can create the advantage of productive resources both from innovations and technological advances. However, its application must pay attention to how the role and function of digital entrepreneurship as a whole to avoid tactics that are not optimal. It is because some criticisms of the entrepreneurial ecosystem began to emerge. Therefore, freedom of relationship and attribution, unit analysis, differences in the use of network resolution, and calculation of existing work matters require special attention (Cunningham, Menter, \& Wirshing, 2019).

Since 2017, BAZNAS has used supporting technology to collect and distribute ZIS funds throughout Indonesia, but the current realization for zakat digitization has only been implemented at the Jakarta Central BAZNAS further developments so that later it can be implemented in other BAZNAS regions in Indonesia. As based on BAZNAS internal and external strategic issues, the development of innovation and digital information technology is one of the backbones of national zakat management. And it was making BAZNAS a role model for the management of world zakat (Puskas BAZNAS, 2016).

The phenomenon of economic disparity and unemployment problems that occur in countries of the Islamic world and have links with the development of digital technology and the potential of zakat empirically requires a solution. Therefore, the research intends to reveal the role of BAZNAS as a competent Amil zakat institution can be tangible proof of how zakat management and digital technology can collaborate as an effort to create welfare for the people. The main contribution of this research is to contribute knowledge about the management of digital zakat as an alternative in solving the phenomenon of economic inequality, the influence of technology, and the problem of unemployment. 


\section{Potential Acceptance of Zakat as an Instrument of Wealth Distribution}

Potential is a hidden power that has not yet been exploited, hidden talents, or success that has not yet been achieved when in fact there is a possibility to develop and achieve success (Majdi, 2007). While the receipt of zakat is assets obtained from muzzaki that meet the legal requirements of the zakat object, that is, assets must be obtained in a lawful manner, fully owned (not concerned in other people's rights), assets free from debt, assets can develop; valid a year / Haul, enough ratio, and assets must exceed the basic needs (alhajatul ashliyah) (As-Shiddiqy, 2017). There is no specific definition of understanding the potential for receiving zakat. Therefore, based on the basic concepts that have been put forward in the study of fiqh and scholars of the school regarding the receipt of zakat, it can be explained that the potential for receiving zakat can be understood as certain assets with certain conditions and derived from muzzaki which is likely to be obtained so that it can be developed and utilized to be greater to give to those who deserve it. The potential for receiving zakat can be increased by empowering zakat especially productive zakat (Amelia, 2016). Nurhasanah found that to explore the potential of zakat is done by increasing public awareness of the importance of the distribution of zakat and the benefits of zakat on efforts to reduce poverty and social inequality (Nurhasanah \& Suryani, 2018). Muneeza dan Hassan (2014) explained that Amil zakat companies and institutions need a good Islamic governance code and apply Islamic legal principles to optimize the potential and management of zakat based on maqasid ash-sharia.

Relationship between Zakat Management, Digital Entrepreneurship, and Islamic Economic Principles

Digital technology marks a new era in entrepreneurship, where the practice of entrepreneurship in traditional ways and forms of pursuing entrepreneurial opportunities is increasingly questioned and remade. Gaining a deeper understanding of fundamental phenomena requires the conceptual integration and construction associated with digital technology with existing entrepreneurial theories. Nambisan (2017) reveals that the digitalization of entrepreneurial initiatives can imply a series of new assumptions that accompany them, namely in the process and results of entrepreneurship that are smoother or less bound, and a more limited and more distributed entrepreneurial agency. In turn, these assumptions demand new theories in entrepreneurship that will benefit from the careful incorporation of digital technology theories, perspectives, concepts, and constructions. With the rapid adoption of digitalization of crossindustry products and services, entrepreneurial opportunities amid economic uncertainty are increasingly apparent.

Digital entrepreneurship is one of the potential empowerments of millennial businesspeople. The potential for new business development is increasing because of the opportunity to digitize and change business branches from offline to online. The positive impact of digitalization on 
entrepreneurship also occurs in the form of promoting innovation, creating employment opportunities, increasing productivity both socially and economically so that it becomes a priority for governments in various countries (Shane and Venkataraman, 2000; Wong et al., 2005; Sartori et al., 2013; Karimi et al., 2015; Le Dinh et al., 2018). Digital entrepreneurship is a phenomenon that has emerged through the development of information and communication technology. Guthrie (2014) states that digital business is the sale of products or services through electronic networks. Digital entrepreneurship has also attracted people to ask for business in the millennial sector, especially in Indonesia's tertiary institutions (Farani et al., 2017). But the digital entrepreneurial potential of millennial entrepreneurs certainly needs to be developed by various parties. The three parties or triple helix are the government, universities, and organizations or industries that are most conducive to developing innovation (Caniago \& Hayati, 2019).

Along with technological advances, technology can be used as a tool in zakat payment transactions. So far, zakat institutions are more centered on Zakat via the Payroll System (ZPS), which is the payment of zakat through direct deductions from employee salaries by filling in the standing instructions of zakat, whereas besides the role of Customer Relationship Management (CRM) is also needed in zakat institutions (Monjelat \& Jamila, 2018). Whereas digital zakat is limited to financial technology (Fintech in zakat payment), which is collaborating with zakat distributors, crowdfunding platforms that are used to facilitate a donation to zakat institutions and this application can provide more efficient and transparent information. Intelligence artificial (artificial intelligence) allows a computer system to do something that humans can do, such as computer visualization, expert systems, and speech recognition (Puskas BAZNAS, 2019).

By developing potential resources (Spina, Ventura, \& Vaglianisi, 2016), and using Customer Relationship Management (CRM) (Widarwati, Afif, \& Zazim, 2016), and management strategies to change mustahiq to muzzaki (Zumrotun, 2016), will supporting the vision and mission, the goals of zakat institutions and policy support from the government regarding zakat in response to the challenges of zakat institutions to the Era of Technology (Asminar, 2017). Various concerns about the impact of the technological revolution must indeed be considered and the solution sought. The theological concept of Islam based on the Koran and Sunnah will provide a fairly concrete understanding of how zakat management technology should be utilized. However, providing an understanding of the benefits of digitalization is not easy. For this reason, a concept of 'digitgrasping' is needed to analyze people's awareness and involvement in the digital world. Then the spread of broadband technology to promote digital inclusion to overcome the digital divide in society (Philips \& Wiliams, 2018) and the role of educational technology to improve the quality of human resources needed. This is due to the weakening of spiritual values of both individuals and society (Beik \& Arsyanti, 2018)

There is a strong positive relationship between Zakat and the social responsibility of the organization. This shows that zakat contributes positively to the profitability and value of the organization and can be considered as a strategy to maximize returns and improve performance 
and consider aspects of society as a whole (Javaid \& Al-Malkawi, 2018). According to researchers, this can also apply to zakat management institutions that incidentally manage zakat to advance the people's independence and economy. The performance of religious institutions and the growth of zakat institutions show a high positive relationship. The characteristics of religiosity that are sources of innovation will reflect the management of zakat institutions.

Abdullahi (2019) revealed that, "Zakat generates large and measurable social benefits to help people and companies. The role of charity can promote halal business, poverty alleviation and sustainable development, and social responsibility. " If the principles of sharia in the digitalization of good zakat are applied consistently, it will certainly increasingly limit the evil intentions of the elements in the company or institution. This must also be supplemented by concrete and explicit rules that force companies to adopt the principles of Good Corporate Governance as guidelines for corporate governance (Aspan, 2017).

One of the advantages of Islamic principles in digitizing zakat is to increase the efficiency and effectiveness of the zakat institute program. A study revealed that using the required savings method for earning zakat recipients can increase the success of zakat institute programs (Hassan \& Noor, 2015). The results of research tests conducted indicate that the motivation for paying zakat income is influenced by the application of good zakat management and the culture of zakat management organizations (Setia \& Zulkifli, 2018). Based on research conducted by Farouk, it is stated that policy formulation is needed to strengthen the zakat payer's intention to fulfill their obligations (Farouk, Idris, \& Saad, 2018). The results of Nature's research on new innovations in the management of zakat from an Islamic perspective states that "The built-in openness and transparent nature of Islamic organizations can increase effectiveness in diversifying products and risks and in developing a segmented market of Islamic products (Choudhury \& Alam, 2013)." To realize a fair distribution of zakat, of course, it requires an Amil Zakat Institution that can maximize the potential of zakat itself. The Amil Zakat Institute as it has existed since the time of Rasullah's leadership until the Era of Digital Technology Transformation requires the management of Amil Zakat as based on the Islamic Economic System.

The ease with which digital technology is given will not completely dominate all forms of human activity, especially those related to a sense of 'attachment' that is born from the faith and sense of responsibility among humans as servants of Allah SWT. The basic values of sharia economics related to creed, sharia and morals are able to give birth to solidarity ( $u k h u w a h$ ) where there is a close bonding relationship with the surrounding environment. Second is the technological problem in the era of digitization which has a negative impact on humans. Research conducted by Park, Hong, and Shin (2019) states findings that support the negative impact of digital technology, where the digital transformation Megatrend basically disrupts and changes the attitudes of industry, business, and most jobs quickly.

The researcher tries to find the source of the Islamic economics approach to find the real truth of the research statement. It is important to understand that even though the phenomenon that occurs today is a decrease in labor because the effects of technology does not mean to be a threat 
if humans know that God guarantees his servant fortune with the conditions that must be known, namely carrying out his request and avoiding his prohibitions. Therefore, it needs to be clarified that in the perspective of Sharia Economy, actually what is called the 'threat' of technology for the sustainability of human resources is a 'momentary' impact so that humans further enhance their potential, work hard and worship God. Humans have a guarantee of fortune if they follow the commands of Allah and stay away from His Prohibition. Therefore, based on the results of Firdaus, Beik, Irawan, and Juanda (2012) research explains that humans are faced with technological competition and weakening spiritual values even though materially better in the face of the zakat program. But on the other hand, humans created by Allah SWT have the concept of thinking and potential so that it can optimally demonstrate their ability to survive and be a mercy to the universe (TA'DIB, 2014). Theory of Technology Determinism (Social Construction of Technology) supports this understanding and explains that humans make up technology (Marx, 1994).

The distribution of zakat is a part of economic and social needs based on the main objective of the sharia economy, giving birth to a multidimensional social intelligence relationship that is able to realize the benefit of the people. The results of Beik, Syauqi Beik, and Arsyianti (2016) research explain that the existence of zakat distribution programs increases the welfare index of zakat. The essence and nature of mankind to obtain prosperity is to protect the faith (ad-din), soul (an-nafs), reason ( $a l$ l'aql), descendants (an-nasl), and wealth ( $a l-m a l$ ), Animate people to take good actions and give birth to mental attitude as well as the quality and quantity of material needs, utilize resources for the public interest, and create human resources that have resilient souls, able to have positive implications for the environment and vision of the mission far ahead (Ghofur, 2016).

This study uses a literature review method with an Islamic economic approach to provide a conceptual discussion about the management of digital zakat by BAZNAS. Development of BAZNAS digital zakat management uses secondary data obtained from the BAZNAS Information \& Documentation Management Officer (PPID), previous studies, and valid online media to support research results.

\section{Discussion}

\section{General Description of the National Amil Zakat Agency (BAZNAS) Central}

"BAZNAS (National Amil Zakat Agency) is an official body established by the Indonesian government based on Presidential Decree No. 8 of 2001, which has the main duties and functions of distributing ZIS (zakat, infaq, and sadaqoh). Puskas (Center for Strategic Studies) BAZNAS conducts studies and research to develop the potential for the management and distribution of zakat to be optimal. In addition, as an effort to contribute to the world of scientific knowledge, especially Muslims. And the most strategic one is as mandated by Law No.23 / 2011 regarding the placement of BAZNAS as a non-structural government institution that is independent and is responsible for managing zakat nationally. "The 2019 BAZNAS strategic plan is contained in the 
National Coordination Meeting (Rakornas) agreement dated 10-12 May 2016 in Jakarta, which was then published in the Decree of the Chair of BAZNAS No.12 of 2016 concerning the Designation of the Team for Changing the Strategic Plan for the 2016 National Amil Zakat Agency."

In the management of national zakat, seven principles are fundamental to maintain the "sustainability" of BAZNAS as stipulated in Law No.23 of 2001 concerning the Management of Zakat. The purpose of the principle in the zakat management system at BAZNAS is meaningful; 1) Islamic Sharia namely that zakat is an obligation for Muslims. Both the payment and distribution of zakat must be in accordance with the provisions of the Sharia; 2) Trust where the manager of zakat must be trusted in managing the zakat of the people; 3) Utilization, that is, giving benefit to the wider community; 4) Justice as a form of distribution of zakat evenly and fairly; 5) Legal certainty to guarantee legal certainty for muzzaki and mustahiq; 6) Integrated in managing zakat in a hierarchical manner to strive to increase the collection, distribution, and utilization of zakat; and 7) Accountability as a form of responsibility to the community

Meanwhile, to realize the rise of national zakat, BAZNAS must do six aspects namely; 1) Aspects of legality include the issuance of Decree of establishment of institutions and Decree of elements of leadership of Provincial BAZNAS and Regency / City BAZNAS; 3) Accountability and suitability aspects where every year there is a form of accountability BAZNAS and audited ats financial statements by the Public Accountant Office (KAP) and sharia audits; 4) Aspects of IT and systems such as the implementation of SiMBA is a centralized application without having to go through a complicated installation process; 5) Distribution aspects based on the core principle of zakat to assess the performance of zakat distribution which can be seen from the ratio of distribution to the collection of zakat; 6 ) The collection aspect which is pursued through education of muzakki in the form of a national zakat campaign; and 7) Aspects of developing Amil to improve and standardize Amil's capacity and competency nationally.

The summary of several BAZNAS strategy studies aims to optimize zakat management in poverty alleviation efforts as follows; (1) Had Kifayah. According to Puskas BAZNAS in the Had Kifayah Study Book 2018, "Had Kifayah is a limit of adequacy or basic standards of individual/family needs plus the amount of adequacy of the dependents that exist with the aim of determining the eligibility of accepting poor mustahiq that is adjusted to the geographical and socio-economic conditions of the region. As a note that according to Puskas BAZNAS, "The Amount of Had Kifayah is higher than the standard poverty line and lower than the standard of decent living which is then used as the standard for determining minimum wages; (2) Apostasy Prone Index. Puskas BAZNAS conducted an Apostasy Prone study to make the Permutant Prone Index Instrument for the district / city level), analyzing permutant vulnerability based on the index value describing the vulnerability index in Indonesia to the district level. Apostasy is a change, change, or conversion to a religion that occurs to every Muslim who has a weak creed. In contrast, the IRP 
(Apostasy Prone Index) is a tool used to measure the level of apostasy vulnerability in a district/city. The variables used in the Apostasy Prone Index consist of; Information access, social culture, education, economy, missionary identity, and health.

This study is very useful and is expected to help minimize the vulnerability of apostasy and help converts in getting zakat from BAZNAS; (3) Risk Management of Zakat Management. In carrying out its duties and functions, BAZNAS has various internal and external risks. According to the BAZNAS Pusaks, "Risk in the context of muzakki is a potential event, both predictable and unanticipated that can negatively impact the level of trust, sharia compliance, and business process sustainability. Therefore, risk management is needed to be used to indicate, measure, monitor, and control risks arising from business activities. " The importance of risk management of zakat management including a) provide regulators with information about risks, ensure that zakat institutions do not experience opportunity-loss, minimize the opportunity-loss of various risks, and measure risk exposure and concentration. The framework for identifying risk management is divided into 11 types of risk consisting of; zakat strategic risk, corporatization, zakat education, operations, property, Amil and volunteers, muzzaki and mustahiq, zakat transfer between countries, reporting, law, and zakat institution compliance risks; (4) Zakat Literacy Index. The background of this Zakat Literacy Index study is to see that the total collection of Zakat BAZNAS which continues to increase every year. PUSKAS BAZNAS hopes that this study can be a benchmark to determine the level of public knowledge of zakat and see people's behavior in the performance of zakat in Indonesia. Zakat literacy index method can be done with 2 (two) dimensions: Basic Knowledge of Zakat and Advance Knowledge of Zakat (Puskas BAZNAS, 2019). As a living document, the study of Zakat Literacy Index has limited time and space. Therefore, this dimension will continue to experience changes and developments in line with the situation and conditions of zakat management in Indonesia.

\section{Effectiveness of Digital Technology Utilization on Zakat Management}

A simple linear regression analysis revealed that the digitalization of zakat is an important component that can be one of the indicators to optimize zakat management. The positive and highly correlated relationship is proof that the distribution of zakat in the economic field after the digitalization of zakat has increased. Research conducted by Saharuddin, Anggraini, and Jamila supports this finding. Research reveals that digital zakat has high efficiency and effectiveness on the receipt of 2016-2017 BAZNAS zakat funds (Saharuddin, Anggraini, \& Jamila, 2019). Thus, it can be understood that the digitization of zakat payments has an effective and efficient value on the receipt of zakat. The results of Djaghballaou and others (2018) also support the results of this study. According to the research results, the existence of technology implementation will affect the efficiency and effectiveness of the Amil zakat institution.

Research conducted by Waheed explains that the use of technology used for specific purposes 
is a potential opportunity because digital platforms are the most widely used by consumers/communities (Waheed, 2019). In other words, the use of zakat payment digitalization can be a potential opportunity for the receipt of Zakat BAZNAS. The findings were made by Young Won, Hong, and Shin revealed that the higher capability of utilizing digital transformation technology contributes to digital technology utilization (Park, Wong, \& Shin, 2019).

Even though the realization of the potential for receiving zakat is still low, the possibility of the opportunity to receive zakat using digital zakat can still be increased (Puskas BAZNAS, 2019). The realization of the potential for receiving zakat is not optimal due to the low efficiency and effectiveness of zakat management in Indonesia (Mubarok \& Fanani, 2014). The results of interviews with the manager of BAZNAS digital zakat support this finding, the efficiency, and effectiveness of digital zakat affect the acceptance of digital zakat. Weak internet networks in certain regions, the need for competent human resources in digital technology, and the cost of utilizing technology are one of the main obstacles. Therefore, according to Rahmawati (2008), the huge cost of utilizing technology requires optimal digital technology use. "Based on data from the BAZNAS PPID, Optimization has indeed continued to be carried out by BAZNAS, but until now, the realization of digital zakat receipts is still in the moderate category compared to the potential for zakat receipts in Indonesia.

Mubarok and Fanani (2014) found that the performance of zakat collection can influence the potential for zakat revenue. This is the reason for the importance of digitizing the payment of zakat, which can control the potential for receiving BAZNAS. The results of Uberbacher et al (2019) explain that "Utilization of digital technology can affect an organization's performance. The specific nature of digital technology can influence the way organizations use their resources. " This means that digitization of zakat is one of the ways BAZNAS uses its resources so that the performance of zakat management can be optimized.

Although it does not mean that it is fully influenced by digital technology, this can be an assumption that digital zakat contributes to poverty alleviation efforts. Indeed, digital zakat must be able to continue to innovate to follow the needs and developments of globalization. Based on data obtained from PPID BAZNAS, "Digital technology has been used in the practice of zakat management and collection, distribution of zakat, and as a means of zakat education; (1) Management and Collection Division. Digital zakat is the collection of zakat through mobile non banking, meaning that digital zakat does not directly manage zakat by muzzaki through mobile banking. It is because mobile banking is carried out directly by the bank and is included in conventional zakat payment transactions. BAZNAS uses blockchain technology to increase the transparency of zakat management institutions in collaboration with Desto in the i-Zakat application. While in the field of collection, there are three platforms provided for raising ZIS funds (zakat, infaq, and sadaqah).

The BAZNAS digital platform until November 2019 has developed into five large platforms 
held by five digital fundraising people. The total exiting platforms are 41 platforms and the total on process platforms are 8 platforms. BAZNAS digital partners on the commercial platform will collect zakat for later submission or transfer to the digital zakat division. Digital zakat collection activities through this platform are carried out in accordance with a certain nominal amount within a period of weeks/month, depending on the size of the collection of zakat. For muzzaki who are abroad, Paypol can be used as zakat digital media. Zakat is paid in dollars (\$) which will be converted. Even for zakat in the form of shares and mutual funds already available. Hafiza revealed that this was done solely to make it easier for muzakki to pay zakat, so there is no longer a reason not to pay zakat for Muslims.

The highest collection of digital alms is before the holy month of Ramadan. Zakat collected can go up to more than $100 \%$ or more. Many of the muzakki pay zakat when the time is nearing the end of the month of Ramadan or before Eid-ul-Fitr to anticipate that zakat distribution can be carried out at the same time as the increase in digital zakat collection rates, BAZNAS uses the prediction of zakat bailout funds to then be distributed to mustahiq; (2) Distribution and utilization of Zakat. The distribution and utilization program of zakat is based on the BAZNAS Welfare Index in the good category with a value of 0.7. In the economic field, BAZNAS developed four programs under the coordination of the Directorate of Distribution and Utilization of BAZNAS, the four programs are ZCD (Community Development Zakat) in 76 villages in 50 districts / cities throughout Indonesia, BMFi (BAZNAS Microfinance), LPEM (Mustahiq Economic Empowerment Institute) ), and LPMM (Mustahiq Animal Empowerment Institute). To support the program, the support of technology is used by BAZNAS in the distribution of zakat. The latest digital technology innovations that have been made are through the Rice for Poor Families Program with the Rice Acceptance Platform (ATM). By attaching the Rice ATM card to the Platform Machine, the rice will come out according to a predetermined range.

In practice, collaboration with stakeholders has also been carried out, for example, by synergizing with the Directorate General of Poor Management of the Ministry of Social Affairs, which gave birth to the National Mustahiq Database System, where BAZNAS gained access to 104 million poor under national management. Second, the Mustahiq Entrepreneur Program through Digital Entrepreneurship. The purpose of this program is to provide venture capital, intensive assistance in developing business to market products through e-commerce, good financial records, building disability confidence, and encourage the strengthening of spiritual mentality based on Islamic economics. The business categories are micro, small, and medium enterprises (MSMEs). This type of business is a household scale business and creative industries and services. This program is also given to persons with disabilities. Assistance is carried out in three stages, namely a) the growth and formation of groups; 2) strengthening to grow mustahiq business activities; and 3) the last stage is independence; (3) Zakat Education Facilities. BAZNAS uses technology to help people get information about zakat more easily through virtual assistants and Facebook Messenger chat. Zakat Virtual Assistant is a chatbot named @zakibaznas that uses 
Artificial Intelligence technology to reply to messages with the chatbot to analyze user desires through the LINE application asking the amount of zakat to be paid. This technology is equipped with Natural Language Process (NLP). The purpose of using 'Zaki' is to respond to users in making transactions and obtain information to interact. Facebook Messenger Chat is used to calculate the amount of zakat accurately, literacy and zakat education, and information on various social and humanitarian programs of BAZNAS.

\section{Digital Entrepreneurship Development}

The entrepreneur program mustahiq through digital entrepreneurship is a major part in new innovations in the field of the distribution of BAZNAS. This program aims to provide venture capital, intensive assistance in developing businesses to market products through e-commerce, good financial records, building defective beliefs, and encouraging the strengthening of a spiritual mentality based on Islamic economics. Micro, small and medium business (MSME) category is household and industrial-scale businesses and creative services. This program is also given to people with disabilities. Assistance is carried out in three stages, namely a) the growth and formation of groups b) strengthening the growth of mustahiq business activities, and c) the last stage is independence.

This is in line with research conducted by Davidsson and Vaast (2015), which explains that to build the nature of entrepreneurship in digital economic practice is to include three different types of related opportunities: what business will be developed, the knowledge needed to support activities, and protection. In addition, it is essential for stakeholders to be aware of differences, opportunities, threats to achieve mutual success; otherwise, digital businesses run a big enough risk to fail. Wind (2008) explains that digital business represents a shift from rational management to network orchestration; as a network, the community is significant for stakeholders.

The things that are an important part of digital entrepreneurship practice are starting from the initial business process, namely, how to develop initial ideas to get results from hard work. There are three important components in the development of digital businesses: the development of ideas, the development of beginner businesses, and subsequent business management (Le Dinh et al, 2016). Finding a stable business in a promising business environment can be the first step in a trial of digital entrepreneurial practice. The primary key is entrepreneurial social networking and capital (Spiegel et al, 2016).

As expressed by Caniago \& Hayati (2019), the development of digital entrepreneurship requires collaboration from three parties, namely the government, universities or universities and industry. First, the Department of Communication and Information recently launched a policy related to the digital start-up movement. The role of the Indonesian government in making policies will greatly influence the development of new digital entrepreneurs, of course, with the good work of BAZNAS as the manager of zakat in the country. Second, the role of universities in terms of education and digital entrepreneurship research. Research through higher education laboratories 
is of great potential for the development of novice entrepreneurial practices. Farani et al (2017) revealed that higher entrepreneurial knowledge in universities when the practice of entrepreneurship is carried out had added higher digital entrepreneurship intention. But the problem is, universities in terms of disseminating knowledge, have limited digital entrepreneurial knowledge and the lack of collaboration between universities and industry in solving industrial technology.

And the last is the role of third parties, namely the development of digital entrepreneurship carried out by third parties. The role of BAZNAS takes over the role as an extension of collaboration. It brings together industry parties that have resources and universities that have the ability and development of research and technology for technological innovation. BAZNAS has launched various digital entrepreneurship scholarship and training programs to support the successful development of digital entrepreneurship on an ongoing basis. The role of the mediator will make it easier for both parties to complement each other's limitations. And also able to enhance the development of digital entrepreneurship programmed by BAZNAS, especially for the poor, to improve their economic well-being.

\section{Conclusion}

Based on the discussion results, it can be concluded as follows; (1) BAZNAS has managed zakat, which is according to the regulations and principles of Islamic economics. This can be known from BAZNAS activities in mustahiq empowerment programs to achieve maqasid ash-sharia; (2) The positive influence of the distribution of digital zakat in the economic field is one proof that digital zakat has an essential role in poverty alleviation. A robust correlation relationship indicates that digital zakat can be an alternative in optimizing zakat management by amil zakat institutions; (3) In the economic field as well, digital technology has become a supporting factor in optimizing the mustahiq empowerment program through digital entrepreneurship and rice atm. Thus, it has been proven that the strategic program, especially the digital zakat launched by BAZNAS can be one of the role models of the world of zakat in zakat management. In practice, it still requires competent human resources to support optimal control.

\section{Acknowledgments}

This work was supported by the National Amil Zakat Agency (BAZNAS) Scholarship Agency No. 216 / Eks / LBB / 10/2019. We want to thank the Master Program of Sharia Economics Study Program and the Postgraduate of The State Islamic University (UIN) Raden Intan Lampung Indonesia, Faculty of Social and Political Sciences, University Muhammadiyah Jakarta (UMJ), and all colleagues for their contribution to this research. 


\section{References}

Abdullahi, Shafiu Ibrahim. (2019). 'Zakah as Tool for Social Cause Marketing and Corporate Charity: A Conceptual Study'. Journal of Islamic Marketing, 10(1), 191-207. doi: 10.1108/JIMA03-2017-0025.

Abror, Khoirul. (2017). Fiqh Ibadah [Fiqh of Worship], cet.1. Yogyakarta: Ladang Kata.

Ahmad, M. (2019). An empirical study of the challenges facing zakat and waqf institutions in Northern Nigeria. ISRA International Journal of Islamic Finance, doi: 10.1108/IJIF-04-20180044 .

Amelia, N. (2016). Analisis Potensi Zakat Dalam Upaya Pengentasan Kemiskinan di Kalimantan Selatan [Analysis of the Potential of Zakat in Poverty Alleviation Measures in South Kalimantan]. Jurnal Humaniora Teknologi, 2 (1), doi: 10.34128/jht.v2i1.2 .

Asnaini. (2008). Zakat Produktif Dalam Perspektif Hukum Islam [Productive Zakat In Perspective of Islamic Law], Cet. 1. Yogyakarta: Pustaka Pelajar, available at: Google Scholar.

Asminar. (2017). 'Pengaruh Pemahaman, Transparansi Dan Peran Pemerintah Terhadap Motivasi Dan Keputusan Membayar Zakat Pada BAZNAS Kota Binjai' [The Influence of Understanding, Transparency And The Role Of The Government On Motivation And The Decision To Pay Zakat In Binjai City BAZNAS], At-Tawassuth, 3.3, 260-81, doi: 10.30821/ajei.v2i2.1222.

As Shidiqie, T.M. Hasby. (2017). Pedoman Zakat [Zakat Guidelines]. Jakarta: P.T Pustaka Rizki Putra.

Aspan, Henry. (2017). 'Good Corporate Governance Principles in the Management of Limited Liability Company'. International Journal of Law Reconstruction, 1(1). pp. 87, doi: 10.26532/ijlr.v1i1.1637.

Beik, Irfan Syauqi \& Arsyianti, Laily Dwi. (2018). 'Measuring Zakat Impact on Poverty and Welfare Using Cibest Model', Journal of Islamic Monetary Economics and Finance, 1(2). 141-60, doi: 10.21098/jimf.v1i2.524.

Canggih, Clarashinta., Fikriyah, Khusnul \& Yasin, Ach. Potensi dan Realisasi Dana Zakat Indonesia [Potential and Realization of Indonesian Zakat Funds], Al-Uqud: Journal of Islamic Economics (1), 2007, p. 14-26, doi: 10.26740/al-uqud.v1n1.p14-26.

Caniago, Indra \& Hayati, Kumala. (2019). Digital Technology Entrepreneurship; Potential Millennial Business Empowerment. Prosiding Sefila, 135-138. http://repository.lppm.unila.ac.id /15444/1/KEWIRAUSAHAAN \%20 TEKNOLOGI\%20DIGITAL_INDRA\%20C.pdf

Choudhury, Masudul Alam \& Alam, Mohammad Nurul. (2013). 'Corporate Governance in Islamic 
Perspective', International Journal of Islamic and Middle Eastern Finance and Management, 6(3). pp. 180-99, doi: 10.26740/al-uqud.v1n1.p14-26.

Cunningham, JA, Menter, M., \& Wirsching, K. (2019). Entrepreneurial ecosystem governance: A research-centered governance framework. Small Business Economics, 52 (2), 545-562, doi: 10.1007/s11187-017-9959-2.

Davidsson, P. (2015). Entrepreneurial opportunities and the entrepreneurship nexus: A reconceptualization. Journal of Business Venturing, 30, 674-695, doi: 10.1016/j.jbusvent.2015.01.002.

Divisi Riset dan Kajian Pusat Kajian Strategis BAZNAS. (2019). Dampak Zakat Terhadap Kesejahteraan Mustahik: Evaluasi Program Zakat Produktif 2018 [The Impact of Zakat on Mustahik's Welfare: Evaluation of the Productive Zakat Program 2018], ed. by Pusat Kajian Strategis BAZNAS Jakarta Pusat, available at: Google Book.

Djaghballou, C. E., Djaghballou, M., Mousa Larbani, A. M., \& Mousa Larbani, A. M. (2018). "Efficiency and productivity performance of zakat funds in Algeria", International Journal of Islamic and Middle Eastern Finance and Management, doi:10.1108/IMEFM-07-2017-0185.

Farouk, Abu bakar U., Idris, Kamil Md., \& Saad, Ram Al Jaffri Bin (2018). 'Moderating Role of Religiosity on Zakat Compliance Behavior in Nigeria', International Journal of Islamic and Middle Eastern Finance and Management, 11(3). pp. 357-73, doi: 10.1108/IMEFM-05-20170122.

Farani, A. Y., Karimi, S., \& Motaghed, M. (2017). The role of entrepreneurial knowledge as a competence in shaping the career intentions of Iranian students to start a new digital business. European Training and Development Journal, 41 No. 1: 83-100, doi: 10.1108/EJTD-07-20160054.

Firdaus, M., Beik, I. S., Irawan, T., \& Juanda, B. (2012). Economic estimation and determination of Zakat potential in Indonesia. Jeddah: Islamic Research and Training Institute, available at: Google Scholar.

Ghofur, Ruslan Abdul. "Peran Instrumen Distribusi Ekonomi Islam Masyarakat [The Role of Instrument of Distribution of Islamic Community's Economy], "IKONOMIKA, Journal of Economics and Business Economics Islam, 1.1 (2016), 27-39, doi: 10.24042/febi.v1i1.140.

Guthrie, C. (2014), "Digital factories: direct learning projects in digital entrepreneurship", Journal of Entrepreneurship Education, Vol. 17 No. 1, p. 115-133, available at: Google Scholar.

Hassan, Nubani Md \& Noor, Abd Halim Mohd. (2015). 'Do Capital Assistance Programs by Zakat Institutions Help the Poor?', Procedia Economics and Finance, 31(15). 551-62, doi: 
10.1016/S2212-5671(15)01201-0.

Hasan, A., Hassan, R., Ali, E. R. A. E., Ali, E. M. T. E., Abduh, M., \& Noordin, N. H. (2019). A proposed human resource management model for zakat institutions in Malaysia. ISRA International Journal of Islamic Finance, doi: 10.1108/IJIF-10-2017-0036.

Javaid, Saima \& Al-Malkawi, Husam Aldin Nizar. (2018). 'Corporate Social Responsibility and Financial Performance in Saudi Arabia: Evidence from Zakat Contribution', Managerial Finance, 44(6). 648-64, 10.1108/MF-12-2016-0366.

Karimi, S., Biemans, H.J.A., Mahdei, K.N., Lans, T., Chizari, M. and Mulder, M. (2015), "Testing relationship between personality characteristics, contextual factors and entrepreneurial intentions in developing countries ", International Journal of Psychology, Vol. 5 No. 1, doi: 10.1002/ijop.12209.

Kashif, M., Jamal, K. F., \& Rehman, M. A. (2018). The dynamics of Zakat donation experience among Muslims: a phenomenological inquiry. Journal of Islamic Accounting and Business Research, doi: 10.1108/JIABR-01-2016-0006.

Laldin, M. A., \& Furqani, H. (2016). Innovation versus Replication: Some Notes on the Approaches in Defining Shariah Compliance in Islamic Finance. Al-Jami'ah: Journal of Islamic Studies, 54(2), 249-272, doi: 10.14421/ajis.2016.542.249-272.

Le Dinh, T., Vu, M.C. and Ayayi, A. (2018), "Towards a living lab for promoting the digital entrepreneurship process ", International Journal of Entrepreneurship, Vol. 22 No. 1, pp. 1-17, available at: Google Scholar.

Lyytinen, K., Yoo, Y., \& Boland, R.J., Jr. (2016). Digital product innovation within four classes of innovation networks. Information Systems Journal, 26(1), 47-75, doi: 10.1111/isj.12093.

Majdi, Udo Yamin Efendi. (2007). Quranic Quotient. Jakarta: Qultum Media, available at: Google Scholar.

Manzhur, Ibnu. (t.th). Lisanul 'Arab, 7:6, Huruf Zai, Lema Zakah, Dar ash-Shadir li ath-Thaba'ah wan-Nasyr wat-Tauzi Cet I Jilid I, Bairut: Dar Shadir.

Mansur, C. M., Suliyanto, S., \& Rahab, R. (2019). Value of Innovation and Marketing Performance. International Review of Management and Marketing, 9(3), 127, available at: Google Scholar.

Marx, M. R. S. L. (1994). Does technology drive history ?: The dilemma of technological determinism. Mit Press, available at: Google Scholar.

Mintzberg, H. (1989). Mintzberg on management: Inside our strange world of organizations. Simon and Schuster, available at: Google Scholar. 
Muneeza, Aishath \& Hassan, Rusni. 'Shari'ah Corporate Governance: The Need for a Special Governance Code', Corporate Governance (Bingley), 14.1 (2014), 120-29, doi: 10.1108/CG02-2011-0015.

Mubarok, A. \& Fanani, B. Penghimpunan dana zakat nasional (Potensi, realisasi dan peran penting organisasi pengelola zakat) [Collecting national zakat funds (Potential, realization and important role of zakat management organizations)]. Permana (2014), 5 (2), available at: Google Scholar.

Mohieldin, M., Iqbal, Z., Rostom, A., \& Fu, X. (2011). The role of Islamic finance in enhancing financial inclusion in Organization of Islamic Cooperation (OIC) countries. The World Bank, available at: Google Scholar.

Monjelat, Natalia \& Jamila, Siti. (2018). 'Analisis Efisiensi \& Efektivitas Zakat Payroll System Dan Zakat Digital Terhadap Penerimaan Zakat Pada BAZNAS Periode 2016-2017'[Analysis of Efficiency \& Effectiveness of Zakat Payroll System and Digital Zakat Against Zakat Receipt in 2016-2017 BAZNAS'], Director. 1-104, available at: Google Scholar.

Nambisan, S. (2017). Digital entrepreneurship: Toward a digital technology perspective of entrepreneurship. Entrepreneurship Theory and Practice, 41 (6), 1029-1055, doi: 10.1111/etap.12254.

Nasution, M. (2004). Manajemen Transportation [Transportation Management]. (M.Qadhafi, Ed.). Bogor: Ghalia Indonesia.

Nurhidayatie, Nurul., Ali, Muhamad \& others. (2015). 'Developing a Multidimensional Performance of Zakat Collection System in East Coast Region', Procedia - Social and Behavioral Sciences, 164. 84-90, doi: 10.1016/j.sbspro.2014.11.054.

Nurhasanah, S., \& Suryani, S. (2018). Maksimalisasi Potensi Zakat melalui Peningkatan Kesadaran Masyarakat [Maximizing the Potential of Zakat through Increasing Public Awareness]. JEBI (Jurnal Ekonomi dan Bisnis Islam), 3(2), 185-194, doi: 10.15548/jebi.v3i2.177.

Park, Y. W., Hong, P., \& Shin, G. C. (2019, August). Digital Transformation Technologies and Capabilities of Technology Utilization: Case Study of Japanese Firms. In 2019 Portland International Conference on Management of Engineering and Technology (PICMET) (pp. 1-4). IEEE, doi: 10.23919/PICMET.2019.8893933.

Pamudji, Sugeng. (2013). Kembali Pada Sistem Ekonomi Islam: Penyadaran Secara Komprehensif [Back to the Islamic Economic System: Comprehensive Awareness], Jurnal Islamica, 3(2): pp. 82,http://jurnal.unimus. ac.id/index.php /vadded/ article/ view/693.

Pemerintah Republik Indonesia, 'Salinan Undang-Undang Nomor 23 Tahun 2011 Tentang 
Pengelolaan Zakat', in Peraturan Pemerintah Republik Indonesia Nomor 14 Tahun 2014 ['A copy of Law Number 23 of 2011 concerning Management of Zakat ', in Government Regulation of the Republic of Indonesia Number 14 of 2014], 2014, pp. 1-52, https://www.bphn.go.id/data/documents/14pp014.pdf.

Pusat Kajian Stategis (PUSKAS) BAZNAS. Outlook Zakat Indonesia 2019 (Pusat Kajian StrategisBadan Amil Zakat Nasional (PUSKAS BAZNAS) [Indonesia Zakat Outlook 2019 (Strategic Study Center-National Amil Zakat Agency (PUSKAS BAZNAS)], 2019. https://puskasbaznas.com/

Philip, Lorna \& Williams, Fiona. (2018). 'Remote Rural Home Based Businesses and Digital Inequalities: Understanding Needs and Expectations in a Digitally Underserved Community', Journal of Rural Studies. 1-13, doi: 10.1016/j.jrurstud.2018.09.011.

Rahmawati, D. Analisis Faktor Faktor yang Berpengaruh Terhadap Pemanfaatan Teknologi Informasi [Analysis of Factors that Influence the Use of Information Technology]. Jurnal Ekonomi dan Pendidikan (2008), 5 (1), doi: 10.21831/jep.v5i1.606.

Republika.co.id. Anggota OKI akan masuk Forum Zakat Dunia [OIC members will enter the World Zakat Forum]. [Media Online; 31 Okt 2019, 11:11 WIB]. https://republika.co.id/berita/q07zs2313/anggota-oki-akan-masuk-forum-zakat-dunia

Sabiq, Sayyid. (1983). Fiqh al-Sunnah, Juz III. Beirut: Daar al-Fikr. Available at: Google Scholar.

Saharuddin, D., Anggraini, R. T., \& Jamila, S. (2019). Efficiency and Effectiveness of Zakat Payroll System and Digital Zakat on the Acceptance of Zakat Funds Baznas 2016-2017. Maqdis: Journal of Islamic Economic Studies, 4 (1), 35-44, doi: 10.15548/maqdis.v4i1.209.

Sartori, R., Favretto, G. and Ceschi, A. (2013), "The relationships between innovation and human and psychological capital in organizations: a review ", The Innovation Journal: The Public Sector Innovation Journal, Vol. 18 No. 3, article 2, available at: Google Scholar.

Setia, Muda \& Zulkifli. (2018). 'Pengaruh Penerapan Corporate Governance ( GCG )' [The Effect of Implementing Corporate Governance (GCG)], 26(1). pp. 48-68, doi: 10.32477/jkb.v26i1.264.

Shaikh, S. A. (2016). Zakat Collectible in OIC Countries for Poverty Alleviation: A Primer on Empirical Estimation. International Journal of Zakat, 1 (1), 17-35, doi: 10.37706/ijaz.v1i1.4.

Shane, S. and Venkataraman, S. (2000), "The promise of entrepreneurship as a field of research ", Academy of Management Review, Vol. 25 No. 1, pp. 217-226, doi: 10.2307/259271.

Spina, Lucia Della., Ventura, Claudia \& Viglianisi, Angela. (2016). 'Enhancement and Governance of the Local Tourist Destinations in Integrated Perspective', Procedia - Social and Behavioral Sciences, 223. 327-34, doi: 10.1016/j.sbspro.2016.05.379.

Spiegel, O., Abbassi, P., Zylka, M., Schlagwein, D., Fischbach, K. and Schoder, D. (2016), "Business 
model development, founders' social capital and the success of early stages internet start-ups: a mixed-method study ", Information Systems Journal, Vol. 26 No.5, pp. 421-449, doi: 10.1111/isj.12073.

Syuryana, Wahyu \& Murdaningsih, Dwi. (2018). Alasan Pentingnya Digitalisasi Zakat, Khazanah [Reasons for the Importance of Digitizing Zakat, Khazanah]. Url: https://www.republika.co.id/berita/dunia-islam/ wakaf /18 /11 /15/pi83kx368-alasan-pentingnyadigitalisasi-zakat, Pada tanggal 25 juli 2019.

Todaro, M. P., \& Smith, S. C. (2003). Economic growth. Financial Times / Prentice Hall.

überbacher, R., Ceipek, R., Hautz, J., Matzler, K., \& De Massis, A. (2019, July). Digital IoT Technology, Firm Performance and Family Involvement: A Resource Utilization Perspective. In Academy of Management Proceedings (Vol. 2019, No. 1, p. 14697). Briarcliff Manor, NY 10510: Academy of Management, doi: 10.5465/AMBPP.2019.14697abstract.

Waheed, B. (2019). Utilization of Wearable Technology: A synthesis of literature review (No. 738). EasyChair, available at: Google Scholar.

Widarwati, Estu., Afif, Nur Choirul \& Zazim, Muhamad. (2016). 'Strategic Approach for Optimizing of Zakah Institution Performance: Customer Relationship Management', Al-Iqtishad: Journal of Islamic Economics, 9(1). pp. 81-94, doi: 10.15408/aiq.v9i1.4010.

Wind, Y.J. (2008), "A plan to invent the marketing we need today", MIT Sloan Management Review,Vol. 49 No. 4, pp. 21-28, available at: Google Scholar.

Wong, P.K., Ho, Y.P. and Autio, E. (2005), "Entrepreneurship, innovation and economic growth: evidence from GEM data ", Small Business Economics, Vol. 24 No. 3, pp. 335-350, doi:10,1007 / s11187-005-2000-1, doi: 10.1007/s11187-005-2000-1.

Zumrotun, Siti. (2016). 'Peluang, Tantangan Dan Strategi Zakat Dalam Pemberdayaan Ekonomi Umat' ['Opportunities, Challenges and Strategies of Zakat in Empowering the Economic Community], Jurnal Hukum Islam, Vol. 14, No. 1, Juni 2016 49-63, 14, 46-63, doi: 10.28918/jhi.v0i0.669. 